\title{
ESCOLA, LOCUS ESPECIAL PARA O ENCONTRO ENTRE FILOSOFIA E EDUCAÇÃO
}

A escola nos parece o locus especial para situar as temáticas discutidas no âmbito de mais este número da RESAFE. Novos encontros são apresentados como possibilidades multiplicadoras de nossos olhares e pensares sobre a interface entre filosofia e educação. Desta forma nossa revista continua a buscar contribuir para este relação, que consideramos significativa e necessária.

$\mathrm{O}$ artigo de André Gustavo Ferreira da Silva apresenta uma discussão da relação entre liberdade e educação em Hegel, procurando demonstrar que, para Hegel, a noção de liberdade fundamenta o movimento progressivo da educação ao longo da história da humanidade.

$\mathrm{O}$ artigo de Fernando Bonadia de Oliveira busca trazer uma reflexão sobre o capítulo 9, da parte IV da Ética de Espinosa, no qual Espinosa afirma que os humanos que se conduzem pela razão procuram educar os demais para que vivam nesta mesma razão.

$\mathrm{O}$ artigo de Ivair Fernandes de Amorim reflete, a partir da literatura e da iconografia, concepções de infância, trazendo conceitos como: Devir Criança e Infância da Educação. Assim como, o emprego educacional da filosofia e da literatura como possibilidades de novas perspectivas em relação aos temas.

$\mathrm{O}$ artigo de Marcos Alexandre Alves e Gomercindo Ghiggi pretende compreender o diálogo e sua importância em uma educação ética. A partir de Gadamer e Freire, os autores afirmam o diálogo com espaço de tolerância e condição para construção de uma educação ética, em que verdade e moralidade possam surgir. Com Lévinas, os autores, buscam refletir sobre a relação interhumana, que se fundamenta na resposta à alteridade. Por fim, afirmam a ética, a relação inter-humana $e$ alteridade, como elementos significativos para o desenvolvimento do processo educativo.

O artigo de Paula Ripamonti procura refletir sobre a diferença nos contextos escolares, buscando explorar as categorias de respeito e solidariedade como 
possibilidade de caminhos que permitam pensar de outro maneira as relações que constroem a prática educativa.

O artigo de Renê José Trentin Silveira discute o papel da história da filosofia no ensino de filosofia, a partir de Antonio Gramsci. Pretende com isto demonstrar a importância da história da filosofia como possibilidade formativa da cultura e do pensamento crítico.

O relato de experiência apresentado por Carmen Sanches Sampaio, Tiago Ribeiro e Igor Helal apresenta reflexões sobre a prática realizada em uma turma de alfabetização, visando pensar novas possibilidades de uma prática educativa em que as crianças sejam reconhecidas como produtoras de conhecimentos.

Esperamos que este número seja mais um convite ao encontro entre educadores, filósofos-educadores, educadores-filósofos, filósofos e quem mais desejar, de modo a multiplicarem-se cada vez mais nossos olhares e pensares sobre educação e filosofia.

Álvaro Sebastião Teixeira Ribeiro 